\title{
Chapter 3 \\ Open Innovation and Value Creation in Crop Genetics
}

\author{
Mathias L. Müller and Hugo Campos
}

\subsection{Origins of Agriculture}

The evolution of human society is closely associated with, and has been dependent on, the progress man has made in agriculture. Therefore, it is no surprise that the field of agriculture has been a particularly fertile ground for innovation. The Neolithic Revolution, at the start of the Holocene calendar, about 12,000 years ago, marks a transition period during which our ancestors' lifestyles changed from hunting and gathering to cultivating crops and growing livestock (Bocquet-Appel 2011). The fertile crescent in the Middle-East, from upper Egypt to the Persian Gulf, including the southeastern regions of Turkey and the western fringes of Iran, are often called the "cradle of civilization" for the fact that sedentism and farming emerged there first (Maisels, 1993), fundamentally transforming the way of life of previously nomadic groups of hunter-gatherers. The dawn of agriculture (from Latin ager = "field" and cultura = "growing, cultivation") was made possible by a warming of the earth's temperatures by approximately $20{ }^{\circ} \mathrm{C}$ following the last ice age, as could be inferred from ice cores collected in Greenland (Platt et al. 2017). The increasingly stable climate made the cultivation of crops and the raising of animals feasible and more reliable. Over the next two millennia, similar developments to those in the fertile crescent occurred and gave rise to the eight centers of origin of agriculture and their derived crops (Vavilov 1951). While the transformation of lifestyles had a profound effect on the environment through the practice of

Mathias Müller is a Corteva Agriscience employee. Corteva Agriscience is a for profit agricultural company.

M. L. Müller $(\varangle)$

Corteva Agriscience, Johnston, IA, USA

e-mail: mathias.muller@corteva.com

H. Campos

International Potato Center, Lima, Peru 
local deforestation and irrigation, it also led to fundamental changes in society and the way humans segregated tasks for greater efficiency. Though successful innovation examples can be found in every single aspect of agriculture, we will only describe some of those related to crop breeding, since a comprehensive discussion of past innovations in agriculture is beyond the scope of this chapter.

\subsection{Innovations in Crop Breeding}

Wild grains were collected and eaten from at least 20,000 BC by hunter-gatherer populations. From around 9,500 BC, the eight Neolithic founder crops, emmer and einkorn wheat, barley, flax, peas, chickpeas, lentils, and bitter vetch, were cultivated in the Eastern Mediterranean regions extending from current Greece to Libya. Rice was domesticated in China around 6,000 BC, followed by mung, soy, and azuki beans (Diamond 1997). Plants which initially succeeded were self-pollinators which were easy to grow, and their early domestication selected for properties such as shatter resistance in wheat for easy harvesting. One of the many benefits of agriculture is greater efficiency. Hunter-gatherer populations were regulated by the amount of food and the number of kills a tribe could achieve. For example, a tribe of 50 might have needed a territory of 100 square kilometers to survive (Tallavaaraa et al. 2018). This in turn meant that the earth could, at most, support a population of 20 million hunter-gatherers. Efficiency became key to population growth and success of the human race; innovations in agriculture made it possible.

It is noteworthy that modern agriculture is capable of supporting today's world population of 7.7 billion, but that important innovations and significant productivity increases are urgently needed to support a world population, projected by the United Nations Department of Economic and Social Affairs to be 9.7 billion in 2050. ${ }^{1}$

Progress in early agricultural practices was slow, progressive, and localized. Earliest cultivators likely combined hunting-gathering with what they managed to grow (Kavanagh et al. 2018), and it took thousands of years to progressively select seeds that were easier to cultivate and provided more nutritious food. Our ancestors did not live in a global society; hence the same innovations had to be made independently in different parts of the world, sometimes thousands of years and miles apart. Weiss et al. (2006) divide domestication of plants into a "gathering" stage, a "cultivation" stage during which plants were sown and harvested, and a "domestication" phase during which mutants with desirable characteristics were selected. For most major food sources, the domestication phase resulted in progressively better cultivars. The process of selection had begun, but it was slow and empirical. The first documented hybrid was achieved by Thomas Fairchild, a "gardener in London" who founded City Gardens, a commercial venture in which he planted and bred

\footnotetext{
${ }^{1} \mathrm{https}: / /$ un.org/development/desa/en/news/population/world-population-prospects-2019.html. Accessed 8/31/2019.
} 
fruits and flowers. He collaborated with botanists and plant collectors through which he was able to obtain plants from around the world. In 1717, he successfully crossed a carnation pink (Dianthus caryophyllus) with a Sweet William (Dianthus barbatus), and the resulting plant, described as Dianthus caryophyllus barbatus, became known as Fairchild's Mule. Significant revolutions in breeding took place in the nineteenth century, starting with Austrian monk Gregor Mendel from Brno (today a historic town in the Czech Republic) who, between 1856 and 1863, formulated what is known as the three principles of Mendel's laws of inheritance, on which modern genetics is based. Mendel focused on seven clearly identifiable traits of pea plants: seed shape, flower color, seed coat tint, pod shape, pod color, flower location, and plant height to elaborate the law of segregation, the law of independent assortment, and the law of dominance (Mendel 1866) which form the basis of Mendelian inheritance patterns, where a trait is controlled by a single locus in an inheritance pattern. Mendel postulated the existence of discrete "factors" (today known as genes) that are passed along from generation to generation. William Bateson, an English professor of biology at Cambridge University and the first director of the John Innes Centre, a leading plant and microbial genetics research organization based in Norwich, United Kingdom, coined the word genetics in 1905.

\subsubsection{Modern Breeding Approaches}

Mendel's laws of inheritance remain the solid foundation upon which modern breeding techniques were developed. For many years, breeding was based on the selection and crossing of the best individuals of a population. The advent of hybrid crops, spearheaded by the development of hybrid maize in the early twentieth century, started a revolution which resulted in a significant acceleration of the incremental yield gain curve in those crops which where amenable to the new breeding techniques. The "Green Revolution" emerged in the 1950s and 1960s, from collaborations and the transfer of technologies between nations, scientists, and farmers. Norman Borlaug, the "Father of the Green Revolution," tirelessly promoted the development of high-yielding grain cultivars and the adoption of improved management techniques, including the use of fertilizers and pesticides and the deployment of irrigation. The selection of cultivars with greater requirements for nitrogen, but also vastly increased yield potential, is credited for saving over a billion people from starvation. The Green Revolution started in Mexico, in collaboration with the US Government, the United Nations, the Food and Agriculture Organization ("FAO"), and the Rockefeller Foundation. From there, the breeding and management techniques expanded to other Latin American countries, Asia, and Africa. One of the great successes of the Green Revolution is rice cultivar IR8, which was derived, in the Philippines, from a cross between the Indonesian variety Peta and the Chinese variety Dee-geo-woo-gen by scientists at the International Rice Research Institute ("IRRI"). While IR8, which is a semidwarf variety resistant to lodging, required the 
supply of fertilizer for optimal production, its harvested yield was almost ten times that of traditional rice.

After the Green Revolution, a large number of innovations dramatically enhanced the ability of plant breeders to accelerate breeding processes. Scientists used information encoded in DNA to capitalize on the genetic diversity contained within cultivars and to enhance the efficiency and effectiveness of plant breeding endeavors. These innovations helped reduce the number of breeding cycles required to bring to market a new variety and accelerated the development of novel elite parents and improved cultivars, fulfilling the needs of humankind. The combined set of modern breeding innovations enabled tremendous increases in genetic gain and resulted in the development of maize hybrids which exhibit commercially relevant levels of drought tolerance and contain stacked transgenic events conferring resistance to insects and tolerance to herbicides, mediated by multiple modes of action. Table 3.1 describes some of the pivotal innovations which have enabled the development of current breeding programs in crop species.

Table 3.1 Main innovations enabling current public and private breeding programs

\begin{tabular}{l|l|l}
\hline Innovation & Impact in plant breeding & $\begin{array}{l}\text { Key reference/ } \\
\text { review article }\end{array}$ \\
\hline Doubled haploid plants & $\begin{array}{l}\text { Reducing breeding cycles and facilitating the } \\
\text { expression of recessive traits }\end{array}$ & $\begin{array}{l}\text { Kasha and Kao } \\
\text { (1970) }\end{array}$ \\
\hline Transgenic plants & $\begin{array}{l}\text { Expanding the range of genetic variation } \\
\text { available to plant breeders and farmers }\end{array}$ & Horsch et al. (1985) \\
\hline $\begin{array}{l}\text { Restriction fragment length } \\
\text { polymorphisms }\end{array}$ & $\begin{array}{l}\text { First truly molecular marker available to gain } \\
\text { insight on the organization of crop genomes }\end{array}$ & $\begin{array}{l}\text { Helentjaris et al. } \\
(1986)\end{array}$ \\
\hline $\begin{array}{l}\text { Linear mixed statistical } \\
\text { models }\end{array}$ & $\begin{array}{l}\text { Improved statistical analyses, increasing the } \\
\text { genetic signal to environmental noise ratio } \\
\text { and the quality of phenotypic datasets }\end{array}$ & $\begin{array}{l}\text { Gilmour et al. } \\
(1997)\end{array}$ \\
\hline Quantitative trait loci & $\begin{array}{l}\text { Examining commercially relevant } \\
\text { quantitative traits with molecular markers, } \\
\text { establishing the basis of molecular breeding }\end{array}$ & $\begin{array}{l}\text { Paterson et al. } \\
(1998)\end{array}$ \\
\hline Genetic modelling & $\begin{array}{l}\text { Ex ante quantitative simulation of genetic } \\
\text { models, genotype-to-phenotype } \\
\text { relationships, and breeding scenarios }\end{array}$ & $\begin{array}{l}\text { Podlich and Cooper } \\
(1998)\end{array}$ \\
\hline $\begin{array}{l}\text { Sequencing of the first } \\
\text { plant genome, Arabidopsis } \\
\text { thaliana }\end{array}$ & $\begin{array}{l}\text { Establishing the basis to understand the } \\
\text { molecular basis of plant variation }\end{array}$ & $\begin{array}{l}\text { The Arabidopsis } \\
\text { Genome Initiative } \\
(2000)\end{array}$ \\
\hline Genomic selection & $\begin{array}{l}\text { Using genome-wide, instead of discrete } \\
\text { molecular markers information, in molecular } \\
\text { breeding }\end{array}$ & $\begin{array}{l}\text { Bernardo and Yu } \\
(2007)\end{array}$ \\
\hline Gene editing & $\begin{array}{l}\text { Unprecedented precision to create and } \\
\text { manage genetic variation and improve traits } \\
\text { in crops }\end{array}$ & $\begin{array}{l}\text { Wolter et al. (2019), } \\
\text { Chen et al. (2019) }\end{array}$ \\
\hline
\end{tabular}




\subsection{Collaborations}

\subsubsection{International Organizations}

Innovations derived from collaborations have shaped the agricultural landscape since the dawn of times. While passionate scientists, in academia or in the private sector, often collaborated to advance their research (see Thomas Fairchild, who documented the first hybrid crops), so did seed companies and equipment manufacturers. In some instances, collaborations between individuals allowed the most significant progress; in others it was collaboration between institutions. Serendipity often played a role. For example, consider the remarkable story of John Washington Carver, who was born into slavery and became one of the most influential agricultural scientists of his time. It is certainly his friendship with young Henry A. Wallace that influenced the latter to experiment with cultivars of maize and later to bring hybrid maize lines to Midwest farmers through the Hi-Bred Corn Company, ${ }^{2}$ which he founded. Upon visiting Mexico as the newly minted US vice president under Franklin Roosevelt's administration, Henry A. Wallace discovered that, while maize was an essential staple in Mexico, the yields obtained by local farmers were far below those achieved in the United States. This recognition and his passion for increasing the yields of crops to feed the world encouraged Wallace, with support of the Rockefeller Foundation, to help set up an experimental station in Mexico, which would encourage collaboration between local farmers and US scientists. Norman Borlaug was one of the first scientists to join the station as a plant pathologist, together with soil scientist William E. Colwell and potato breeder John Niederhauser. The three are largely credited for being at the origin of the green revolution for which Norman Borlaug eventually earned his Nobel Peace Prize in 1970. In the middle of the twentieth century, rapid population growth triggered fears of widespread global famine. The Mexican government had established the Office of Special Studies (OSS) to coordinate the program initiated by the Rockefeller Foundation. This in turn laid the groundworks for the establishment and support of the International Rice Research Institute (IRRI) in 1960 and the International Maize and Wheat Improvement Center (CIMMYT) in 1963. In 1970, the Rockefeller Foundation proposed a broader coalition to support an international network of agricultural research centers and, with the help of the World Bank, the FAO, and UNDP, established the Consultative Group for International Agricultural Research (CGIAR) to reduce poverty and achieve food security in developing countries. Today, the CGIAR comprises 15 independent nonprofit research centers (Table 3.2), conducting innovative research and collaborating on a global scale.

\footnotetext{
${ }^{2}$ Which later became Pioneer Hi-Bred International, Inc., and is now part of Corteva Agriscience.
} 
Table 3.2 Global network of CGIAR centers

\begin{tabular}{|c|c|}
\hline CGIAR centers & Headquarters location \\
\hline Africa Rice $^{\mathrm{a}}$ (West Africa Rice Development Association, WARDA) & Abidjan, Côte d'Ivoire \\
\hline Bioversity International & Rome, Italy \\
\hline Center for International Forestry Research (CIFOR) ${ }^{\mathrm{b}}$ & Bogor, Indonesia \\
\hline International Center for Tropical Agriculture (CIAT) ${ }^{\mathrm{c}}$ & Cali, Colombia \\
\hline $\begin{array}{l}\text { International Center for Agricultural Research in the Dry Areas } \\
\text { (ICARDA) }\end{array}$ & Beirut, Lebanon \\
\hline $\begin{array}{l}\text { International Crops Research Institute for the Semi-Arid Tropics } \\
\text { (ICRISAT) }\end{array}$ & Hyderabad, India \\
\hline International Food Policy Research Institute (IFPRI) & $\begin{array}{l}\text { Washington, D.C., United } \\
\text { States }\end{array}$ \\
\hline International Institute of Tropical Agriculture (IITA) & Ibadan, Nigeria \\
\hline International Livestock Research Institute (ILRI) & Nairobi, Kenya \\
\hline International Maize and Wheat Improvement Center (CIMMYT) & Texcoco, Mexico \\
\hline International Potato Center (CIP) & Lima, Peru \\
\hline International Rice Research Institute (IRRI) & Los Baños, Philippines \\
\hline International Water Management Institute (IWMI) & Battaramulla, Sri Lanka \\
\hline $\begin{array}{l}\text { World Agroforestry Centre (International Centre for Research in } \\
\text { Agroforestry, ICRAF) }\end{array}$ & Nairobi, Kenya \\
\hline $\begin{array}{l}\text { World Fish Center (International Center for Living Aquatic } \\
\text { Resources Management, ICLARM) }\end{array}$ & Penang, Malaysia \\
\hline
\end{tabular}

${ }^{a}$ AfricaRice and IRRI joined efforts in 2018 to offer a pan-African, multi-focus rice program ${ }^{\mathrm{b} O n}$ January 1, 2019, the Center for International Forestry Research (CIFOR) and World Agroforestry (ICRAF) effectively merged

c On December 2018, Bioversity International and the International Center for Tropical Agriculture (CIAT) signed a memorandum of understanding to create an alliance

\subsubsection{Public-Private Partnerships}

The public sector has played an enormous role in agricultural innovations, particularly in the United States within the system of land-grant colleges and universities, whose mission, as set forth in the Morrill Acts of 1862 and 1890, was to focus on teaching practical agriculture, science, military science, and engineering. Landgrant universities developed strong breeding programs which became the source of germplasm for American farmers and local seed companies. Academic research was pivotal in the development of hybrid seed programs which, in the case of maize, resulted in the discovery of heterosis, the tendency of a crossbred individual (a "hybrid") to show qualities superior to those of either parent ("inbreds" in the case of maize). The advent of hybrids, with their homogeneous growth across large expanses of Midwestern lands, allowed for the mechanization of agriculture. The deployment of hybrids led to major changes in the American farming system: farm horses were replaced by tractors, and mechanical harvesting replaced labor-intensive 
hand picking of hybrid corn. The transition from varietal breeding to double-cross and eventually single-cross hybrids, combined with improvement in land management techniques, crop protection products, and fertilizer programs, resulted in a threefold increase in maize yields between the 1920s and 1980s (Crow 1998).

Today, public-private partnerships remain an essential foundation of innovation and scientific advances, but the balance of resources devoted to research and development is rapidly changing. While it is undeniable that the private sector benefits greatly from investments made by the public sector in fundamental research and the education of scientists, companies have committed enormous amounts of resources to early stage discoveries to better serve farmers and seek an edge over their competitors. Against a backdrop of proportionally more limited resources for the public sector and innovations which require sophisticated (and expensive) infrastructure, the private sector has invested massively in technology developments, with global private spending on agricultural R\&D rising from $\$ 5.1$ billion in 1990 to $\$ 15.6$ billion by 2014 (Fuglie 2016), whereas the public sector increased at a slower rate. In 1980 , the ratio of private vs. public investments was pegged at 0.54 ; by 2011 , it had increased to 0.81 , coming close to parity (Pardey et al. 2015). But it is not only the absolute amounts invested which have evolved over time, it is also the types of investments, which are undergoing a dramatic transition, particularly in large-scale agriculture.

Large companies in the agricultural sector compete with each other to deliver ever better products and services to their customers, who are increasingly discerning and sophisticated in choosing which products allow for sustainable returns. With farmer productivity being the key driver of an industry, which has innovated at a remarkable clip for close to a century, investments in research and development by the private sector have become a condition of existence. With the collaboration of James Watson and Francis Crick, which in 1953 led to the description of the structure of the double helix of deoxyribonucleic acid ("DNA") (Watson and Crick 1953), plant agricultural research advanced to be conducted at the molecular level. The second half of the twentieth century produced new and powerful scientific technologies, specifically based on recombinant DNA techniques, genetic engineering, rapid gene sequencing, and synthetic biology.

At first, large-scale collaborations focused on elucidating the genetic material of several plant species. The Multinational Coordinated Arabidopsis Genome Project was first, including stock centers in the United States and in Europe orchestrated in the United States by the National Science Foundation. After 10 years, the global collaboration involving scientists from the United States, Europe, and Japan resulted in a near complete Arabidopsis (commonly called thale cress) genome, published in the year 2000 (The Arabidopsis Genome Initiative 2000). Collaborations between academics and scientists from government and private industry were frequent and productive. Databases were built and shared, including by the private industry, like the single nucleotide polymorphisms and small insertions and deletions database constructed from the Columbia and Landsberg erecta ecotypes and made available by Cereon Genomics as a service to the community (Ausubel 2000). This spawned 
a series of large-scale projects aimed at discovering the functions of the 25,000+ genes identified in Arabidopsis thaliana (Bevan and Walsh 2005).

In September of 2002, the National Science Foundation (NSF) announced the launch of the Maize Genome Sequencing Project, but it was not until 2009 that a multi-institutional effort, involving scientists at Washington University in St. Louis, the Cold Spring Harbor Laboratory in New York, the Arizona Genomics Institute, and Iowa State University, resulted in the publication of a series of papers in the journal Science revealing the DNA sequence of maize B73 (Schnable et al. 2009), while in Mexico, scientists published results derived from the ancient popcorn variety palomero (Vielle-Calzada et al. 2009).

But while these initial efforts were largely supported by the public sector, the many billions of genotypic and phenotypic datapoints collected today by seed companies, particularly in the development of hybrid crops, have forced them to invest in infrastructure that dwarfs that of most academic institutions. Together with the curation of proprietary germplasm collections by long operating seed companies, this has allowed the private sector to become the major driver of the record yields that are obtained today with hybrid seeds in the developed world. Even so, collaborations between the public and the private sector remain essential for progress to be made and new inventions to be developed in hybrid breeding and more so with varietal crops, where the germplasm held and developed by universities remains the prevalent source of seeds for many farmers. Furthermore, such collaborations enable the spillover of technological progress to crops relevant in developing countries for which seed companies have not typically developed specific cultivars.

\subsubsection{The Age of Genetically Modified Organisms (GMOs), Technology Alliances, and Biotechnology Startups}

With the advent of a rapidly cycling simple model plant such as Arabidopsis thaliana, where forward genetics allowed academics all over the world to characterize genes with putative functions in plant development and the protection of yield, interactions between the public and the private sector became frequent and sustained, directed toward the elusive goal of extracting more yield from crop plants under normal and stressed conditions through the application of recombinant techniques. Startup companies spun off from universities and corporations and attracted venture capitalists eager to engage in an industry which promised large revenue potential. Calgene, founded in 1980 in Davis, California, was one of the first to believe that genetic engineering could be applied successfully to plant agriculture. Calgene's first product, the Flavr Savr tomato, was engineered with an antisense gene to downregulate the enzyme polygalacturonase which participates in the softening of the fruit and makes it susceptible to being damaged by fungal infections and postharvest handling. As a result, Calgene's Flavr Savr tomato could be harvested later and withstood storage and transport much better than conventional 
tomatoes. Calgene was also engaged in the development of herbicide-tolerant cotton, and canola that was genetically engineered to produce laureate, a key raw material used in the manufacture of soap, detergent, and personal care products.

Plant Genetic Systems ("PGS"), founded in 1982 by Marc Van Montagu and Jeff Schell who, at the University of Ghent, Belgium, and the Max Planck Institute in Germany, respectively, had developed a vector system for transferring foreign genes into the plant genome by using the Ti plasmid of Agrobacterium tumefaciens, is credited for significantly advancing the field of plant biotechnology. PGS was the first startup company to engineer tobacco plants with a gene encoding the insecticidal protein from Bacillus thuringiensis (Bt). DNA Plant Technology ("DNAP") was founded in 1981 by William R. Sharp and David A. Evans, in New Jersey, before moving to California "to develop tastier, value-added plant-based products for industrial and consumer markets" 3 through the use of advanced plant breeding systems, tissue culture, and later transgenic techniques. And with the advent of Arabidopsis genetics, companies were founded to explore gene structure-function relationships. Companies like Ceres Inc., founded in 1996 to explore gene expression patterns and functions; Mendel Biotechnology, Inc., founded in 1997 to understand gene expression through the study of transcription factors; and Paradigm Genetics, Inc., founded in 1997 to focus on functional genomics, became the new breed of innovators trying to revolutionize the industry. The new startup companies quickly formed strategic partnerships with major seed and trait developers such as Monsanto, Bayer, and DuPont. The large investments made by these seed companies to finance collaboration with the startups, combined with the support of venture capitalists, allowed for a golden age of small plant biotechnology companies which emerged in Belgium, the San Francisco Bay Area, Southern California, the Research Triangle Park of North Carolina, and progressively elsewhere in locations associated with major university centers.

For the next 10 years, further innovations involving recombinant techniques led to ever more innovative companies. DNA shuffling (or directed molecular evolution), a method for in vitro recombination of homologous genes, was invented by Dr. Willem ("Pim") Stemmer while working at Affymax Inc. Stemmer's invention led to the foundation of Maxygen, Inc., a startup company, which further developed the technology and innovated in the field of agronomic trait discovery and optimization through its Verdia, Inc. subsidiary. Maxygen and Verdia ${ }^{4}$ formed several alliances, including with Pioneer Hi-Bred, Syngenta, and Delta \& Pine Land Company, to "provide proprietary product solutions to important commercial problems in plant-based businesses through the application of advanced trait optimization methods."

\footnotetext{
${ }^{3}$ https://en.wikipedia.org/wiki/DNA_Plant_Technology

${ }^{4}$ Author MM was employed by Maxygen and Verdia, Inc.
} 


\subsection{Closed Innovation}

During most of the twentieth century, inwardly focused research and development $(\mathrm{R} \& \mathrm{D})$ in industry enabled substantial achievements and many commercial successes.

In many countries, academic scientists were at the time more interested in the process of scientific discovery to gain insights about the physical world than in putting such knowledge into practical use. At that time, it was common among academic camps to dismiss researchers inclined toward applied applications of science, on the ground that they were sold to corporate interests and therefore considered greedy.

Therefore, and with the benefit of hindsight, during most of the twentieth century, pursuing R\&D within a firm was one of the few options available to those interested in practical applications of science, and it became the de facto dominant design among large, multinational companies. Internal $\mathrm{R} \& \mathrm{D}$ divisions were considered a strategic asset that needed to be carefully nurtured and shielded from the external world and competitors. The world knew little about corporate innovations until scientific developments became launched and commercialized in the form of products (Chesbrough 2003).

After the Second World War, the US government made increasingly large amounts of funding available, not only to government labs but also to the large number of independent universities being created. The availability of more research grants and scholarships enabled a dramatic increase of the pool of talent educated at the graduate level in many fields of science. In addition, during the 1990s, private funding for R\&D activities in developed countries caught up to public R\&D budgets. The combination of additional funding, both public and private, and a larger pool of talent led to the golden era of corporate labs in firms such as DuPont, Bell Laboratories, General Electric, IBM, RCA, Xerox in the United States, BASF, Bayer, Roche, Nestlé, Unilever, Siemens, and Shell, among many others in Europe, and "keiretsu" conglomerates such as Mitsui, Mitsubishi, Sumitomo, and Sanwa, among others, in Japan.

The mindset was one of "closed innovation", and was based on the principle that companies were, by and large, on their own in terms of developing the technologies needed to sustain and increase their market footholds. It is during this period that the unfortunate "not invented here" motto was coined, reflecting an inward stance where firms could simply not afford to rely on scientific developments created outside the corporation, be these of public or private nature. From a strategic standpoint, internal R\&D capabilities were seen as an entry barrier to discourage potential competitors (Chesbrough 2003).

Closed innovation created a subtle, and sometimes not so subtle, tension between research and development activities. For instance, while scientists in centralized, corporate research labs were driven to move into the next wave of innovative projects, instead of delving deeper into commercially relevant work, researchers in development felt the pressure to find out more about how to translate such research 
outputs into commercial products. In addition, while research usually represents an SGA (selling, general, and administrative) cost item from a budgetary perspective, development is typically allocated to business units and structured as part of profit and loss statements. Therefore, a functional and financial disconnect between research and development activities became more prevalent in many large corporate R\&D organizations (Chesbrough 2003).

In more recent years, the closed innovation mindset has found itself increasingly at odds with the way that knowledge currently flows. There are several aspects which have severely undermined and challenged closed innovation, the most relevant being:

1. The availability of an increasingly more mobile pool of skilled researchers. Companies can build upon others' investments in a more effective way than before, for instance, through hiring skilled staff from other companies or through contracting consultants who provide advanced expertise in specific areas.

2. The availability of venture capital, which enables startups to pursue both research and development activities in a nimbler way than larger corporations. Venture capital has enabled independent startups within the agricultural domain with the funding needed to make significant and fast progress. For instance, Inari, a nextgeneration seed company which develops traits and cutting-edge technologies based on gene editing, raised $\$ 89$ million in its series $C$ financing round, ${ }^{5}$ whereas Provivi, a company developing novel methods to control agricultural pests using naturally occurring pheromones, has raised over $\$ 36$ million through its series $\mathrm{B}$ financing round. ${ }^{6}$

3. The increasing availability of external suppliers of $R \& D$, both in numbers and in terms of the expertise they provide. For instance, the success in the ability to develop commercially effective Bt genes (used to develop biotech seeds with intrinsic resistance to insect damage) by Dow (now Corteva Agriscience) and Monsanto (now Bayer) can be traced back to the access of extensive libraries of Bt genes developed by smaller, specialized companies with a strong expertise in the field, such as Mycogen ${ }^{7}$ and Ecogen, ${ }^{8}$ respectively. While the development of transgenic drought traits has fallen short of expectations, with only Monsanto's DroughtGard ${ }^{\mathrm{TM}}$ hybrid maize reaching project launch status, 20 years of R\&D and collaborations with startup companies such as Mendel Biotechnology, Ceres Inc., or Evogene have significantly contributed to increasing the scientific community's general knowledge of the molecular basis of drought resistance in plants (Nuccio et al. 2018). In recent years, the trend of favoring early stage discovery at startup companies has become the mainstream, since corporate venturing has allowed a large number of startup companies to be created not only in

\footnotetext{
${ }^{5}$ https://inari.com/wp-content/uploads/2019/08/PR_Inari-Raises-89-Million-to-Bring-InnovativeDisruptive-Technologies-to-Growers-1.pdf

${ }^{6}$ http://provivi.com/provivi-announces-expanded-series-b/

${ }^{7}$ https://www.aphis.usda.gov/brs/aphisdocs/03_18101p_pea.pdf

${ }^{8}$ https://pestweb.com/news/a2768/ecogen-confirms-monsanto-is-using-its-bt
} 
the United States but also globally, some of which have become competitive in research domains such as gene editing and digital agriculture, among others. In 2017 alone, agriculture-related startups raised over $\$ 10$ billion in venture-backed funding, and one of them, Indigo, has already reached unicorn ${ }^{9}$ status.

4. The limited predictability in the usefulness of the extensive intellectual property portfolios companies have built over the years for the development of successful new products. A case in point is that less than $10 \%$ of Procter \& Gamble's patents were used by any of its businesses for product development (Sakkab 2002). While patents can represent an effective trade currency to obtain freedom to operate (e.g., through cross-licensing) and keep litigation at bay, and if one excludes the small number of patents which sustain product launch and commercialization, the ability for a patent owner to translate a large number of them into actual value in the market is, at best, questionable. It is thus likely that making such intellectual property available to other organizations could increase the odds of deriving tangible value from it.

\subsection{Open Innovation}

Agriculture and agrifood companies of all sizes are currently beset with increasing competition and technological complexity, rising R\&D costs, shortened product life cycles, increased expectations from customers, more complex and expensive regulatory processes, and industry consolidation. With improved institutional markets and stronger intellectual property rights, venture capital and technology standards have enabled organizations to trade their knowledge and ideas.

The challenge facing the domain of agriculture and agrifood systems is daunting, with current projections predicting the Earth's population ballooning to 9.7 billion by 2050 , which is only 30 crop growing cycles away from today in the mid- 2020 . Though certain vegetable crops sustain more than one growing cycle per year, and while the climate in some countries such as Brazil and Paraguay also allows a second growing cycle of main crops each year (safrinha), by and large, the global commodities (maize, rice, soybeans, wheat) are only harvested once a year.

To place this challenging problem in context, humankind is going to have to produce as much food over the next 30 years as during the previous 10,000 years, with the added complexity of a reduction in available land per capita; the unpredictability brought about by climate change; an increasing concern by the public about the way crops and food are being produced, packaged, distributed, and commercialized; and the unsustainable fact that a large proportion of the food produced is being wasted.

\footnotetext{
${ }^{9} \mathrm{~A}$ privately held startup company with a current valuation of at least US $\$ 1$ billion is referred to as a unicorn.
} 
One consequence of the above-described conundrum is that even for large, multinational companies, the problem to solve is so large that it becomes untenable to maintain in-house all the expertise, infrastructure, and human talent needed to cover the continuum of activities ranging from fundamental research to those development activities leading to commercial launch inside the organization. Moreover, as described in Frans Johansson's fascinating book The Medici Effect, true innovation has the stubborn habit of coming from beyond your realm of expertise and from what he refers to as the "intersection of ideas."

In today's environment, regardless of their size, firms are quickly evolving from a closed into an open innovation mindset to remain competitive, since the previously successful closed mindset has become a factor stifling progress and reducing the likelihood of innovation success.

Henry Chesbrough from the University of California at Berkeley, who first coined the term open innovation (referred to thereafter as "OI" through this chapter), defines it as "a distributed innovation process based on purposively managed knowledge flows across organizational boundaries, using pecuniary and nonpecuniary mechanisms in line with the organization's business model" (Chesbrough and Bogers 2014). The main tenet of OI is that, in order to thrive in an increasingly competitive market and in a more complex society, firms should open up their boundaries and leverage inflows and outflows of knowledge and technology. In other words, companies should not only establish outside-in channels to source external knowledge but also develop inside-out processes to leverage external paths to novel markets which would otherwise remain off-limits. Figure 3.1 provides a current working model of open innovation. One of the major departures from a closed model is that companies practicing OI explicitly feed their innovations funnels with both, in-house and external developments. This allows them to evolve from the previous "not invented here" syndrome to a "proudly invented elsewhere" framework. In addition, OI enables not only the exploitation of current, known markets but also the exploration of novel ones, which brings about accelerated benefits for society at large, since under a closed model such developments and value creation activities would either never occur, or would take place several years later. Another benefit of OI, when it is linked with corporate entrepreneurship, is that OI efforts can create encouragement, opportunities, and incentives for staff development.

One of the underpinnings of OI is the realization that the knowledge needed to innovate is becoming more widely distributed in the economy and that there is an increased scattering of the sources and providers of such knowledge. Under these premises, the two main working models of OI, namely, outside-in and inside-out innovation, where firms are open to adopting all kinds of external inputs and contributions, while simultaneously allowing some of their technological assets to be used by others, makes sense. In coupled modes of open innovation, outside-in and inside-out modes are combined.

OI can be implemented through several approaches such as in- and out-licensing, spin-ins (or acquisitions) and spin-outs, co-conception and co-development, 


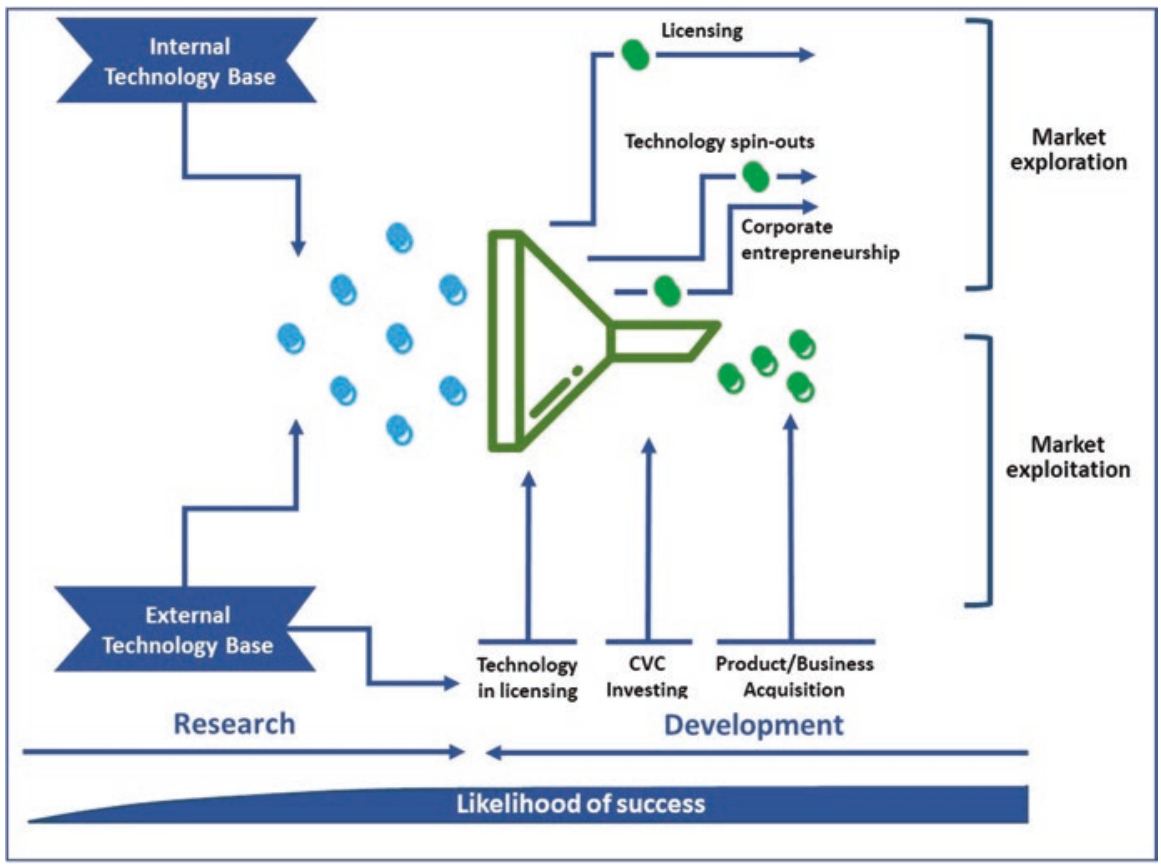

Fig. 3.1 Open innovation

research joint ventures, crowdsourcing, community innovation, and online market places. In some cases, a company implementing OI can also enable employees to exploit a given technology in noncompeting areas or in areas not yet ripe for product development. Furthermore, OI efforts can develop hitherto non-exploited markets through corporate entrepreneurship efforts, as already mentioned. Regardless of the approach, all forms of OI enable a quicker and nimbler flow of knowledge between different actors at the supply and demand ends of the market.

From a conceptual innovation standpoint, OI embraces the "jobs to be done" perspective described in Chap. 1 in this volume, since it aims to reduce satisfaction gaps which create both frustrations in customer and business opportunities for firms that would likely otherwise go unnoticed, or be exploited by competitors.

OI represents the explicit recognition that even for very large companies, it is not in their best interest to attempt to internally address all $R \& D$ aspects to remain competitive but also that for some of their $R \& D$ outcomes, there are unchartered markets previously untapped from which value can be captured by making such outcomes available to other organizations.

In order to understand how diverse organizations create the paths to both engage and benefit from OI, authors such as Linus Dahlander and David Michael Gann have elaborated a capability perspective, which considers the organizational culture and the mechanisms that need to be developed to create innovations (Dahlander and Gann 2010). Differences in capabilities will determine the extent to which a firm 
implements OI and its ability to create value. Furthermore, a capabilities' perspective helps to design OI systems able to become a competitive advantage in a world where technical knowledge doubles every 2 years and where more and more knowledge is either easily distributed or is made available as a public good in the public domain. At the most fundamental level, OI is embedded in the notion that the sources of knowledge for innovation are widely distributed in the economy.

Embracing OI modifies the mindset that companies take to the development of new products. Christensen (2006) points out that to maximize the benefits of OI, companies need to not only possess deep expertise and technological ability but also combine the ability to integrate sourced innovations or intellectual property, manage relationships with different partners, and sometimes adopt a dual, possibly simultaneous role, as both provider and seeker of technology.

\subsubsection{Open Innovation and Intellectual Property}

Open innovation is not open source. Patents are important as they encourage firms to invest in R\&D and to disseminate technical knowledge within the economy. They are granted to a holder by the appropriate national or regional authority and provide limited rights to the patent holder to exclude others from commercially exploiting a given invention over a set period of time, unless the patent holder authorizes them to do so.

Patents are present throughout all the steps of the open innovation process as a structuring element. Initially, they facilitate knowledge inflows through signaling and in-licensing contracts. Then they help to coordinate the production of knowledge by collaborators and competitors, starting with their use as bargaining chips and ending with their potential as contract enforcers. Finally, they help manage the outflows of knowledge and the distribution of profits by enabling either out-licensing strategies or by ensuring the maintenance of exclusivity and its associated profits. As such, in open innovation, firms are not only producers but also active users of patents and other means of intellectual property rights (IPRs) (Pénin and Neicu 2018).

A recent study analyzed the 100 largest R\&D spenders among Swedish national and binational firms, as well as the 100 largest R\&D spenders among Swedish small and medium enterprises, to shed light on the relationship existing between patenting and OI. Patenting with protection (technology protection and safeguarding, blocking competitors from certain technology areas, obtaining freedom to operate (FTO), and creating retaliatory power) and bargaining motives (enabling licensing, crosslicensing, and R\&D collaborations) were positively related with the importance of open innovation strategies. However, the positive relationship between protection motives and open innovation was stronger than that between bargaining motives and open innovation. According to the study, patenting acts as an enabler of open innovation for the individual innovating firm (Holgersson and Granstrand 2017).

Though the abovementioned study used patents, there are additional mechanisms of intellectual property protection. A large study conducted in Spain with over 2,800 
SME firms concluded that, while SMEs do not directly benefit from open innovation or from patenting in the same way as larger firms, they nevertheless profit from alternative ways of protecting the intellectual property associated with their proprietary technologies (Brem et al. 2017).

Regardless, the proper management and availability of IPRs in a general sense exert a positive influence on OI efforts.

\subsection{Open Innovation Comes of Age in Crop Genetics}

The expenses and complexities associated with the development of transgenic traits have kept the development of GMO crops out of reach of most but for the largest companies supplying large scale agriculture with maize and soybean seeds. Because model plant systems were, by and large, unable to predict the effects of multigenic traits affecting yield and other quantitatively inherited traits of importance to farmers, the seed industry relied on an innovation model that became increasingly closed in areas such as transgenic trait development and predictive breeding. However, with the recent consolidation of the industry and the resultant restructuring and focus on product development, a compelling argument can be made that the next decade will see a more open form of innovation, centered around early stage discovery. The phenomenon is not unlike what the pharma industry experienced over the past two decades, with the integration of technologies developed by startups becoming their major source of innovation.

Large, medium, and small seed and plant breeding companies have much to gain from embracing an open innovation model, due to the types of innovations which will be needed by the farming community in the next decade or two and the cost of developing these innovations. Firms in the precision farming sector, which rely on the confluence of many disciplines from the high tech, data management, computer vision, and agronomy sectors, will benefit as well.

The successful deployment of new technologies is dependent not only on farmer adoption but also on the appropriate regulatory framework, which in turn is contingent on the acceptance of such technologies by consumers, the general public, and society at large. Past experience with transgenic traits has shown that in the absence of obtaining a social license to practice the new technologies, consumer acceptance may be difficult or even impossible to obtain. This argues for the large developers of genetics in commodity crops to make their technologies and know-how available broadly to stimulate entities more focused on academic pursuits and the development of public goods to become early adopters and independent champions of such technologies. For example, smaller fruit and vegetable seed companies and nonprofit organizations can harness CRISPR-Cas9 genome editing and associated technologies to develop disease resistance traits creating the potential for more sustainable, nutritious, and affordable products, for both developed and developing 
countries. To enable such a model and also advance its philanthropic aims, DuPont Pioneer (now part of Corteva Agriscience) developed, in 2017, a joint licensing framework with the Broad Institute of Harvard University and the Massachusetts Institute of Technology (MIT) to provide access to CRISPR-based gene editing technologies in plant agriculture. Under the joint licensing structure, the parties made their combined portfolio of over 40 patents available for free to support research conducted by academics, governmental agencies, and nonprofit organizations, as well as for the development of agricultural products destined to smallholder farmers, while also retaining the freedom to license their individual patent portfolio to others. For other licensees, they apply financial terms that are adapted to the licensees' size and revenue prospects.

The long and arduous path that often accompanies the establishment of research and commercial licensing agreements provides additional support for a more open form of innovation. Early stage technologies are highly uncertain, and many remain untested, either due to failure to reach a satisfying win-win situation during negotiations or simply because the negotiation process constitutes a hurdle that the parties are not willing to face. As Fig. 3.1 shows, the likelihood of success of technologies at a very early stage of development is, at best, slight. Settling for simpler, researchonly licensing relationships can open the floodgates that keep less mature technologies from being tested while deferring the negotiation of commercial terms to a time when initial proof of concept is confirmed. Under a closed innovation mindset, such technologies might never be tested. Though this approach might not be adequate for all technologies, it represents an option that both sides of a negotiation might consider.

A further reason for encouraging a more open form of collaboration and innovation is the highly interconnected and interdependent nature of technology developments among many participants in the agricultural technology development sector. Technological and commercial developments rarely happen in isolation but rather derive from the development of networks of agricultural technologies, in which components interact and co-evolve to become increasingly interdependent. One of the reasons for such interdependency is the establishment of separate dominant designs, which create network externalities, complementing each other and lowering the costs of absorbing and mainstreaming new developments.

This creates multitiered hierarchical structures where end-user technologies become dependent upon infrastructure technologies which underlie the solutions stack. This in turn leads to the establishment of platform technologies of increasing relevance in agriculture, not only in commercial terms but also because of their ability to create additional value for customers and to integrate digital, biological, and financial solutions in a more efficient and/or affordable way.

While startups and academics have vast innovative abilities and venture capitalists have resources that can be assigned to the development of new technologies, only the large, international seed companies have the scale and the development resources to bring some of these innovations to market in production agriculture. 


\subsection{The Role of Venture Capital (VC)}

The 1980s and 1990s saw a flurry of entrepreneurs developing their proprietary plant biotechnology innovations through newly formed startup companies. Venture capitalist investment followed the successful strategic partnerships that startups formed with major seed companies, and the first wave of successful exits resulted in acquisitions by the multinationals who became keen to internalize the innovative discovery programs of the startups. However, by 2010, plant biotechnology startups had thinned, venture capitalists had become wary of the long development timelines associated with transgenic crops, and the multinationals had taken advantage of the historically high seed prices of 2008, 2011, and 2012 to invest in and develop their own formidable internal programs. Another realization started to set in: beyond the initial biotech traits conferring herbicide tolerance and insect resistance, agricultural biotechnology's holy grail of increased drought tolerance, yield, and fertilizer use efficiency would require harnessing complex multigenic traits. Model plant systems were largely inadequate to tease out the complex requirements that would result in a successful trait without pleiotropic effects. Interests shifted, and new areas of innovation started to make it to the foreground. The soil and plant microbiomes became an innovation target.

For millions of years, plant and soil microbes have coexisted and benefitted from each other. Microbes decompose organic matters and make nutrients such as nitrogen and phosphorus available to the plants, and the plants supply the carbon needed by the bacteria to survive. In 2009, Bayer Crop Science announced its new VOTiVOTM biological seed treatment, which makes use of beneficial Bacillus firmus bacteria to protect maize, soybeans, and cotton against nematodes. In 2012, Syngenta acquired the startup Pasteuria Bioscience, with which it had partnered since 2011. This was followed in 2013 by the launch of Clariva pn, Syngenta's first biological nematicide seed treatment, which contains spores of Pasteuria nishizawae, an obligate parasitoid of soybean cyst nematodes. The race was on! Bayer acquired California-based AgraQuest in 2012; Monsanto announced a deal with Torrey Pines, CA-based Synthetic Genomics and formed the BioAg Alliance to commercialize microbial products for agriculture with Denmark based Novozymes, the world's largest enzyme producer, both in 2013. The next few years were a golden age for VC and startups in the biological space. Bayer purchased Argentinian Bioagro Group in 2014 and announced a research collaboration with St. Louis, MO-based Elemental Enzymes in 2015. DuPont acquired Taxon Bioscience, a Tiburon, CA-based startup focusing on industrial microbes; and Dow AgroSciences entered a collaboration with UK-based Synthace Ltd., both in 2015. In 2016, Monsanto's corporate venture group invested in California-based Pivot Bio and North Carolina-based AgBiome; in 2017 it led a financing round in St. Louisbased NewLeaf Symbiotics. In 2017, Bayer announced a new partnership with Ginkgo Bioworks to develop microbial products that would stimulate nitrogen fixation in plants, and DowDuPont announced a collaboration with Arysta LifeScience and a multi-year collaboration with Israel-based Evogene, to develop microbial seed treatments for maize. ${ }^{10}$

\footnotetext{
${ }^{10} \mathrm{http} / / /$ www.etcgroup.org/sites/www.etcgroup.org/files/files/info_brief_microbial_and_bayermonsanto_0.pdf - Accessed 8/25/2019.
} 
Another area of intense innovation and startup activity in the last 5-10 years is that of precision agriculture. Further details on this topic are provided by Sonka in Chap. 8 of this volume. At the convergence of big data management, satellite imagery, remote sensing, computer vision, and precision input application technologies, startups and venture capitalists are hustling to develop the technologies that will make farming more data driven, productive, and sustainable. Precision agriculture is not a new concept, as farmers adopted GPS-connected equipment in the 1990s to increase productivity; but with the advent of remote sensing, unmanned aerial vehicles (UAVs, aka drones), high-speed internet, and other technological advancements, precision agriculture is becoming the mainstream. ${ }^{11}$ As it happened with other technologies, the large seed companies invested heavily to develop their digital agricultural services' platforms. The most notable exits in this space are the Monsanto's acquisition of the Climate Corporation in 2013 and DowDuPont's acquisition of Granular in 2017.

Today's farmers have access to an enormous amount of data. But data without integration and management recommendations are of little use. Some of the challenges facing precision agriculture are the integration of big data into a single platform, interpretation of remote sensing and scouting data through crop consultants or apps that make use of artificial intelligence, and the implementation of recommendations about planting decisions and application of inputs across entire farms.

But the area which has perhaps attracted the most interest from scientists, investors, and the public alike is that of genome editing. With the discovery of CRISPRCas9 genome editing technology in 2012, published almost simultaneously by scientists at the Vilnius University, Lithuania (Gasiunas et al. 2012), on one hand, and by scientists at the University of California at Berkeley, the University of Vienna, and Umea University (Jinek et al. 2012) on the other, the field immediately triggered a flurry of entrepreneurial activity, with the founding of multiple startups and massive investments by the venture capital community. The world of plant genetic innovations was once again coming into focus. While genome editing wasn't new in itself, since it had been pioneered through the use of zinc finger nucleases as early as the 1980s and by using meganucleases and TALENs thereafter, CRISPR technology made the precise editing of genomes an affordable and facile endeavor. Before CRISPR, most companies had to resort to using transgenes to bring genetic improvements to market, a process which took in average 13 years and cost $\$ 130 \mathrm{MM}$ for existing products ${ }^{12}$ and was increasingly becoming more costly and taking longer, as the regulatory path became gradually more complicated. This limited transgenic improvements only to major crops such as maize and soybeans, where companies could envision making a return on their investment. With CRISPR technology and the prospects of an appropriate regulatory framework in the United States and other countries recognizing that CRISPR-edited crops are not transgenic crops, the field opened widely to academic researchers and startups.

\footnotetext{
${ }^{11} \mathrm{https}$ ://agfundernews.com/what-is-precision-agriculture.html - Accessed 8/25/2019.

${ }^{12} \mathrm{https}: / /$ croplife.org/wp-content/uploads/pdf_files/Getting-a-Biotech-Crop-to-Market-PhillipsMcDougall-Study.pdf - Accessed 9/2/2019.
} 
There is no doubt that AgTech innovations are experiencing a golden age and that the current venture system represents its lifeblood. Investments funding AgTech startups reached an all-time high in 2015 , with $\$ 4.6$ billion committed, followed by $\$ 4.2$ billion in 2016 .

\subsection{Mergers and Acquisitions}

Consolidation in the seed and crop protection industry over the past decades led to the formation of large organizations uniquely positioned to exploit increasingly complex molecular breeding and transgenic trait development programs. During the golden years of high seed prices, substantial capital investments into large internal discovery engines were made by the multinationals.

Nevertheless, while transgenic input traits, including herbicide tolerance and insect control traits, translated into increased revenues for the seed companies and efficiency gains for farmers, investments committed to the development of transgenic agronomic traits such as intrinsic yield increase, or increased fertilizer efficiency, have yet to deliver value.

With yields increasing steadily and seed stocks in the developed world attaining record highs, commodity prices collapsed and so did the growth of company revenues. This led to yet another round of consolidation resulting in the acquisition of Syngenta by ChemChina, the merger of equals between Dow and DuPont, and the acquisition of Monsanto by Bayer.

The merged firms have consolidated development pipelines which, for years to come, will require large amounts of resources to drive product concepts toward commercial launch. Combined with the need for these firms to reduce their marginal costs, this could put pressure on their investments in early stage discovery, which will result in an opportunity for the startup sector and academics alike to regain an important role in supplying the industry with the cutting-edge technologies of tomorrow.

\subsection{Closing Comments}

Collaborations between the private and public sector have brought about steadily increasing yields. Incredible productivity gains have been obtained by a sophisticated industry that has successfully incorporated advanced technologies. Since the advent of hybrid maize, yields in the United States have increased sevenfold! Corteva Agriscience has built a maize germplasm collection that goes back over 90 years, with phenotypic data that was collected from the start and associated genotypic data built over time. Such continuity in data collection and the coherence of the germplasm pools are unmatched in the private or the public sectors. Combined with an ability to precisely correlate phenotype to genotype for the past two decades, 
the accumulated data allows for increasingly accurate predictions in support of the breeding process, allowing modern breeders to cross inbreds chosen from the germplasm pools to obtain high-performing hybrids that respond to specific biotic and abiotic stress conditions while maximizing yield for the targeted maturity zone. That is the strength of the large agricultural input multinationals. But we are entering an era of complementarity with developers of early stage technologies, whether they are in the public sector or at startups, where the diverse models of open innovation are expected to play a larger role than in the past. The convergence of innovators in a highly technological sector of enormous breadth and scale has the potential to shape the future of agriculture into one that can feed the world's nine billion people in a sustainable and environmentally friendly way.

Acknowledgments Innovation is about people's connections, and we would like to wholeheartedly thank Dr. David Meyer (Corteva Agriscience) for connecting us. Without David's willingness and generosity to put us in touch, this chapter would not have been possible. Hugo Campos acknowledges the financial support of the CGIAR Research Program on Roots, Tubers and Bananas (RTB), supported by CGIAR Trust Fund contributors (https://www.cgiar.org/funders/), and is also very grateful to the support of a Bill \& Melinda Gates Foundation investment (OPP1213329) awarded to the International Potato Center.

We would also like to thank Prof. Henry Chesbrough (University of California at Berkeley) for granting permission to use, and modify, Fig. 3.1.

\section{References}

Ausubel FM (2000) Arabidopsis genome. A milestone in plant biology. Plant Physiol 124:1451-1454

Bernardo R, Yu J (2007) Prospects for genome-wide selection for quantitative traits in maize. Crop Sci 47:1082-1090

Bevan M, Walsh S (2005) The Arabidopsis genome: a foundation for plant research. Genome Res 15:1632-1642

Bocquet-Appel JP (2011) When the world's population took off: the springboard of the Neolithic demographic transition. Science 333(6042):560-561

Brem A, Nylund P, Hitchen E (2017) Open innovation and intellectual property rights. Manag Decis 55(6): 1285-1306

Chen K, Wang Y, Zhang R, Zhang H, Gao C (2019) CRISPR/Cas genome editing and precision plant breeding in agriculture. Annu Rev Plant Biol 70:667-697

Chesbrough HW (2003) Open innovation. Harvard Business School Press, Boston, 227p

Chesbrough HW, Bogers M (2014) Explicating open innovation: clarifying an emerging paradigm for understanding innovation. In: Chesbrough HW, Vanhaverbeke W, West J (eds) New frontiers in open innovation. Oxford University Press, Oxford, United England, pp 1-37

Christensen JF (2006) Wither core competency for the large corporation in an open innovation world? In: Chesbrough HW, Vanhaverbeke W, West J (eds) Open innovation: researching a new paradigm. Oxford University Press, Oxford, UK

Crow JF (1998) 90 years ago: the beginning of hybrid maize. Genetics 148(3):923-928

Dahlander L, Gann DM (2010) How open is innovation? Res Policy 39(6):699-709

Diamond J (1997) Guns, germs, and steel: the fates of human societies. W.W. Norton \& Company. 480 p. ISBN 978-0-393-03891-0. OCLC 35792200 
Fuglie K (2016) The growing role of the private sector in agricultural research and development world-wide. Glob Food Sec 10:29-38

Gasiunas G, Barrangou R, Horvath P, Siksnys V (2012) Cas9-crRNA ribonucleoprotein complex mediates specific DNA cleavage for adaptive immunity in bacteria. Proc Natl Acad Sci U S A 109:2579-2586

Gilmour AR, Cullis BR, Verbyla AP (1997) Accounting for and extraneous variation in the analysis of field experiments. J Agric Biol Environ Stat 2(3):269-293

Helentjaris T, Slocum M, Wright S, Schaefer A, Nienhuis J (1986) Construction of genetic linkage maps in maize and tomato using restriction fragment length polymorphisms. Theor Appl Genet 72(6):761-769

Holgersson M, Granstrand O (2017) Patenting motives, technology strategies, and open innovation. Manag Decis 55(6):1265-1284

Horsch, R. B., Fry, J. E., Hoffmann, N.L., Eicholtz, D., Rogers, S. G,.Fraley, T. A. 1985. A simple and general method for transferring genes into plants. Science 227: 1229-1231

Jinek M, Chylinski K, Fonfara I, Hauer M, Doudna JA, Charpentier E (2012) A Programmable DualRNA-Guided DNA Endonuclease in Adaptive Bacterial Immunity. Science 337(6096):816-821

Kasha KJ, Kao KN (1970) High frequency haploid production in barley (Hordeum vulgare L.). Nature 225:874-876

Kavanagh PH, Vilela B, Haynie HJ, Tuff T, Lima-Ribeiro M, Gray R, Botero C, Gavin M (2018) Hindcasting global population densities reveals forces enabling the origin of agriculture. Nat Hum Behav 2:474-484

Maisels CK (1993) The near east: archaeology in the cradle of civilization. Routledge Press, 241 p. isbn:978-0-415-04742-5

Mendel G (1866) Versuche über Plflanzenhybriden. Verhandlungen des naturforschenden Vereines in Brünn, Bd. IV für das Jahr, Abhandlungen, 3-47

Nuccio ML, Paul M, Bate NJ, Cohn J, Cutler SR (2018) Where are the drought tolerant crops? An assessment of more than two decades of plant biotechnology effort in crop improvement. Plant Sci 273:110-119

Pardey P, Chan-Kang C, Dehmer S, Beddow J (2015) InSTePP's international innovation accounts: research and development spending, version 3.0. InSTePP, University of Minnesota, St. Paul

Paterson AH, Lander ES, Hewitt J, Peterson S, Lincoln SE, Tanksley SD (1998) Resolution of quantitative traits into Mendelian factors by using a complete linkage map of restriction fragment length polymorphisms. Nature 335:721-726

Pénin J, Neicu D (2018) Patents and open innovation: bad fences do not make good neighbors. J Innov Econ Manag 25:57-85

Platt DE et al (2017) Mapping post-glacial expansions: the peopling of Southwest Asia. Sci Rep 7:40338. https://doi.org/10.1038/srep40338. ISSN 2045-2322

Podlich D, Cooper M (1998) QU-GENE: a simulation platform for quantitative analysis of genetic models. Bioinformatics 14(7):632-653

Sakkab N (2002) Connect \& develop complements research and develop at P\&G. Res Technol Manag 45(2):38-45

Schnable PS, Ware D, Fulton RS, Stein JC, Wei F, Pasternak S, Liang C, Zhang J, Fulton L, Graves TA, Minx P, Reily AD, Courtney L, Kruchowski SS, Tomlinson C, Strong C, Delehaunty K, Fronick C, Courtney B, Rock SM, Belter E, Du F, Kim K, Abbott RM, Cotton M, Levy A, Marchetto P, Ochoa K, Jackson SM, Gillam B, Chen W, Yan L, Higginbotham J, Cardenas M, Waligorski J, Applebaum E, Phelps L, Falcone J, Kanchi K, Thane T, Scimone A, Thane N, Henke J, Wang T, Ruppert J, Shah N, Rotter K, Hodges J, Ingenthron E, Cordes M, Kohlberg S, Sgro J, Delgado B, Mead K, Chinwalla A, Leonard S, Crouse K, Collura K, Kudrna D, Currie J, He R, Angelova A, Rajasekar S, Mueller T, Lomeli R, Scara G, Ko A, Delaney K, Wissotski M, Lopez G, Campos D, Braidotti M, Ashley E, Golser W, Kim H, Lee S, Lin J, Dujmic Z, Kim W, Talag J, Zuccolo A, Fan C, Sebastian A, Kramer M, Spiegel L, Nascimento L, Zutavern T, Miller B, Ambroise C, Muller S, Spooner W, Narechania A, Ren L, Wei S, Kumari S, Faga B, Levy MJ, McMahan L, Van Buren P, Vaughn MW, Ying K, Yeh CT, Emrich SJ, Jia 
Y, Kalyanaraman A, Hsia AP, Barbazuk WB, Baucom RS, Brutnell TP, Carpita NC, Chaparro C, Chia JM, Deragon JM, Estill JC, Fu Y, Jeddeloh JA, Han Y, Lee H, Li P, Lisch DR, Liu S, Liu Z, Nagel DH, McCann MC, SanMiguel P, Myers AM, Nettleton D, Nguyen J, Penning BW, Ponnala L, Schneider KL, Schwartz DC, Sharma A, Soderlund C, Springer NM, Sun Q, Wang H, Waterman M, Westerman R, Wolfgruber TK, Yang L, Yu Y, Zhang L, Zhou S, Zhu Q, Bennetzen JL, Dawe RK, Jiang J, Jiang N, Presting GG, Wessler SR, Aluru S, Martienssen RA, Clifton SW, McCombie WR, Wing RA, Wilson RK (2009) The B73 maize genome: complexity, diversity, and dynamics. Science 326(5956):1112-1155

Tallavaaraa M, Eronen JT, Luoto M (2018) Productivity, biodiversity, and pathogens influence the global hunter-gatherer population density. Proc Natl Acad Sci U S A 115:1232-1237

The Arabidopsis Genome Initiative (2000) Analysis of the genome sequence of the flowering plant Arabidopsis thaliana. Nature 408:796-815

Vavilov NI (1951) The origin, variation, immunity and breeding of cultivated plants (translated by K. Starr Chester). Chron Bot 13:1-366

Vielle-Calzada JP, de la Vega OM, Hernández-Guzmán G, Ibarra-Laclette E, Alvarez-Mejía C, Vega-Arreguín JC, Jiménez-Moraila B, Fernández-Cortés A, Corona-Armenta G, HerreraEstrella L, Herrera-Estrella A (2009) The Palomero genome suggests metal effects on domestication. Science 326:1078

Watson JD, Crick F (1953) The structure of DNA. Cold Spring Harb Symp Quant Biol 18:123-131

Weiss E, Kislev M, Hartmann A (2006) Autonomous cultivation before domestication. Science 312:1608-1610

Wolter F, Schindele P, Puchta H (2019) Plant breeding at the speed of light: the power of CRISPR/ Cas to generate directed genetic diversity at multiple sites. BMC Plant Biol 19:176

Open Access This chapter is licensed under the terms of the Creative Commons Attribution 4.0 International License (http://creativecommons.org/licenses/by/4.0/), which permits use, sharing, adaptation, distribution and reproduction in any medium or format, as long as you give appropriate credit to the original author(s) and the source, provide a link to the Creative Commons license and indicate if changes were made.

The images or other third party material in this chapter are included in the chapter's Creative Commons license, unless indicated otherwise in a credit line to the material. If material is not included in the chapter's Creative Commons license and your intended use is not permitted by statutory regulation or exceeds the permitted use, you will need to obtain permission directly from the copyright holder.

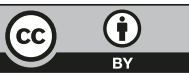

